\title{
Is CLIL Becoming a Hub Connecting Research, Policy, and Practice?
}

\author{
¿Se convierte AICLE en un puerto de conexión \\ entre la investigación, la política y la práctica? \\ AICL torna-se uma conexão de porta entre pesquisa, \\ política e prática?
}

Jermaine S. MCDOUGALD*

\section{INTRODUCTION}

In recent years, ELT practitioners have been concerned about learning as well as the development of learning skills among students. Researchers continue to focus their attention towards the innovative-but not newinsights in terms of turning traditional education towards a more real, useful, motivating, and shared task. Yet educators often find themselves in frustrating situations in the classroom, due to inadequate approaches or methodologies, which in turn limit the success of the teaching and learning process. Nowadays, learners need to be challenged but also prepared for what is outside the classroom: the real world, where the roles of both teachers and students are quite different than before. CLIL (Content and Language Integrated Learning) not only promotes life-long learning skills for learners but also flexibility and a new way of looking at education as a whole, providing learners with specific training that could ultimately benefit their learning process.

* Managing Editor, LACLIL. jermaine.mcdougald@unisabana.edu.co

To reference this article / Para citar este artículo / Para citar este artigo

McDougald, J.S. (2016). Is CLIL becoming a hub connecting research, policy, and practice?, Laclil, 9(1), 7-16. doi:10.5294/laclil.2016.9.1.1 
However, CLIL continues to revolutionize education as a whole and not just programs focused on language. It also provides opportunities for both language and content, a time and time again this approach has demonstrated positive results both inside and outside the classroom while 'exerting a very positive influence on learners' motivation, which goes hand in hand with increased foreign language achievement" (Lasagabaster, 2011, p.15) Which has also been noted in other studies as well (Doiz, Lasagabaster \& Sierra, 2014; Lasagabaster, D. \& Sierra, 2009). This, in itself, can be seen as presenting a contemporary approach to language teaching mixed with subject-area teaching. Nevertheless, CLIL is different in that it can positively respond to the challenges that emerge from a particular setting, thereby helping teachers cope with the needs of the learners.

There is presently a great deal of evolution and development taking place with CLIL, and it is refreshing to see that this approach is no longer only seen in Europe but has expanded to other continents as well. In this volume of the Latin American Journal of Content and Language Integrated Learning (LACLIL), we have the opportunity to show just how CLIL has or is emerging throughout the world.

\section{CLIL CONTINUES TO EXPAND}

The world is demanding that people construct knowledge but also that they be aware of the rapid changes in trends related to the market, economy, technology, communication, and education. Graddol, (1998, 2006a) has often reminded us that we are living in a globalized, postmodern world in which a rather different model of education has emerged: one that takes into consideration the characteristics of an individual who participates fully in the new economy - as a worker, consumer, and responsible citizen-and who needs to be ever better informed (about global as well as local issues). Considering that these changes are happening as we speak, educational institutions need to be able to support their learners so as to become active agents in a globalized world, thereby leading to more multilingual societies. As a consequence, educational systems are under pressure to adapt quickly and accordingly (Coyle, Hood, \& Marsh, 2010), as well as to define new policies related to multilingualism. 
For starters, learners should have a profile that allows them to not only survive but play an active role in a multilingual society; this means that it is necessary for them to be introduced to a successful multilingual policy (Coyle et al., 2010) that ultimately has the potential to "strengthen the life of citizens; it may increase their employability, facilitate access to services and rights and contribute to solidarity through enhanced intercultural dialogue and social cohesion" (Coyle et al., 2010, p.3). All of this and more highlights the need to adapt and reorganize institutions so that they can meet the challenges of $21^{\text {st }}$-century education, integrating languages, content, and cultures. However many countries around the world are starting to implement extensive curriculum reforms with the intention of retooling knowledge-oriented economies required to operate in a globalized world (Graddol, 2006b). In this regard, CLIL has made significant contributions to educational institutions worldwide, as in the cases of Argentina, (Dario Luis Banegas, 2012; Darío Luis Banegas, 2012; Pistorio, 2009), Colombia (McDougald \& Anderson, 2015; McDougald, 2009, 2015; Rodríguez, 2011), and Italy (Aiello, Di Martino, \& Di Sabato, 2015; Costa \& Coleman, 2010; Favilli, Maffei, \& Peroni, 2012; Grandinetti, Langellotti, \& Ting, 2013), as well as in countries such as Canada, the Netherlands, Spain, Hong Kong, the Philippines, and Malaysia, through which we can explore relative successes or failures of a CLIL approach (Costa \& D’Angelo, 2011).

\section{CLIL RESEARCH AND EDUCATION COMING TOGETHER}

These two terms go hand in hand: research and education. However, linking them to CLIL takes us to another level of looking at what is really happening in the classroom to promote $21^{\text {st }}$-century skills. It is interesting to see how CLIL initiatives have spread across South America and throughout the world, and this issue of the Latin American Journal of Content and Language Integrated Learning provides clear examples of how these curriculum reforms and large scale adjustments are starting place outside of Europe. There are 8 different research articles from authors in 8 different countries in this issue: Argentina, Austria, Taiwan, Belgium, the United States, Spain, Canada, and Japan. In each, CLIL researchers are evaluating programs and tools, training teachers, and exploring new pedagogies in 
CLIL, as well as looking at new ways of how CLIL approaches can provide solutions for many at different levels of education worldwide.

This issue starts out in Argentina, where Banegas, (2016) highlights the spread of CLIL throughout Latin America, but specifically in Argentina. He focuses on teacher training and the need for CLIL-oriented professional development, paying close attention to lesson plans, material design, and teaching practices, but also goes further to discuss how the social construction of knowledge within the CLIL framework helps learners develop not only language competences but also non-language content knowledge. Although the topics of materials design and evaluation have, to date, often been neglected in the research though, in the present issue, from Spain, López Medina, (2016) studies the idea of creating a tool to evaluate ELT textbooks/CLIL materials in terms of principles/techniques surrounding foreign language teaching, as well as criteria for producing quality CLIL resources. This study is of considerable interest, given that although many resources and or studies (Massler, Stotz, \& Queisser, 2014; Mehisto, 2012; Meyer, 2010) have become available in recent years, tools to evaluate them and help teachers make sound decisions about using them are, in contrast, much less readily available.

Turning to issues of CLIL classroom practices in secondary education, also in the current issue, from Austria and Belgium respectively Gierlinger and Wagner, (2016) and Ouazizi, (2016) take a closer look at how CLIL is being managed at this level. Although there have been several studies on vocabulary acquisition in CLIL contexts or that highlight classroom practices related to vocabulary acquisition in CLIL classrooms (Canga, 2013; Merikivi \& Pietilä, 2014; Sulista, 2015; Xanthou, 2011), Gierlinger and Wagner's mixed-method study on the acquisition of new vocabulary (in English) through a CLIL setting in an Austrian secondary school highlights that more research and evaluation is needed to clearly establish a relationship between language teaching and vocabulary acquisition using a CLIL approach as their results revealed that CLIL students "fail to outperform" receptive vocabulary growth. In contrast, Ouazizi looks at the effects of teaching math with English using a CLIL approach. Teaching mathematics in English is often a challenge, not least in Colombia, as many teachers tasked with teaching math in English have in fact been trained as English 
language (not math) teachers, as many bilingual institutions appear to feel as if it is enough to just "speak English" to likewise teach content through that language. Nevertheless, research has repeatedly shown that more effective pedagogical practices are desperately needed (Jäppinen, 2005; Novotná \& Hofmannová, 2000), making studies such as Ouazizi's, which finds that CLIL can be more effective than "traditional" approaches, helping learners achieve high proficiency levels in both English and mathematics.

Top-down policy-based support for CLIL implementation has often proved effective. In the current issue, Yang, (2016) looks at the learning efficacy, management difficulties, and improvements in 12 tertiary-level CLILbased programs in Taiwan, revealing that learner satisfaction with the CLIL approach is greatly affected by learners' language proficiency, as well as providing numerous insights into the current situation of CLIL in Taiwan where there are excellent possibilities for making curricular changes to content and foreign language curricula. Also dealing with the implementation of CLIL in Asia in this issue, Toh, (2016) examines both the curricular and ideological issues surrounding English as a Medium of Instruction (EMI) and English for Academic Purposes (EAP) at a Japanese university, considering whether they are viable options at this level, and finding that EMI/ EAP approaches lack true opportunities for academic inquiry (Toh, 2016).

Although much work on CLIL has focused on English as the vehicular language, it needs to be emphasized that CLIL is not an "English only" approach. In this issue, from the United States, Enkin and Mejías-Bikandi, (2016) discuss the benefits of using online translators in an advanced-level Spanish foreign-language classroom in higher education. They find that students and teachers can both take advantage of faulty online translators, and activities using these can be created to help raise metalinguistic awareness about L2 grammar and differences between grammatical constructions in the L1 and L2. Also in this issue, McGregor, (2016) examines the cognate effect and lexical processing in 3 groups (English-dominant, Spanish-dominant, Bilinguals combined) of highly proficient English-Spanish and Spanish-English bilinguals in a university setting, finding clear differences in how the three participant groups performed in how L1 or L2 and vice versa influenced one another in terms of their production. However, as a result of the high level of language proficiency in L2 (English), McGregor was able 
to see how this directly influences or even interfere with dominant, native language production.

Clearly, much remains to be explored regarding CLIL implementation as a response to meeting global needs in education as well as multilingual communication and multiculturalism. Nevertheless, as Coyle et al., (2010) have argued, it is impossible to select just one CLIL model capable of addressing all the variables all contexts. Is CLIL is becoming a hub connecting research, policy and practice? This issue of LACLIL alone provides us with 8 different examples from 8 different countries of how CLIL continues to evolve around the world - and thereby with quite a few new ideas to help as answer that question, demonstrating how CLIL researchers and practitioners are closing the gap between language, content, education, and policy.

\section{REFERENCES}

Aiello, J., Di Martino, E. \& Di Sabato, B. (2015). Preparing teachers in Italy for CLIL: reflections on assessment, language proficiency and willingness to communicate. International Journal of Bilingual Education and Bilingualism, 0050(November), 1-15. http://doi.or g/10.1080/13670050.2015.1041873

Banegas, D. L. (2012). CLIL Teacher development: Challenges and experiences. Latin American Journal of Content and Language Integrated Learning. http://doi.org/10.5294/laclil.2012.5.1.4

Banegas, D. L. (2012). Integrating content and language in English language teaching in secondary education: Models, benefits, and challenges. Studies in Second Language Learning and Teaching, 2(1), 111136. Retrieved from http://www.unifg.it/sites/default/files/ allegatiparagrafo/20-01-2014/banegas_integrating_clil.pdf

Banegas, D. L. (2016). Teachers develop CLIL materials in Argentina: A workshop experience. Latin American Journal of Content and Language Integrated Learning, 9(1), 17-36. doi:10.5294/laclil.2016.8.1.2

Canga, A. (2013). The receptive vocabulary of Spanish 6th-grade primaryschool students in CLIL instruction: A preliminary study. Latin 
American Journal of Content and Language Integrated Learning, 6(2), 22-41. http://doi.org/10.5294/laclil.2013.6.2.2

Costa, F. \& Coleman, J. a. (2010). Integrating content and language in higher education in Italy: ongoing research, 1(3), 19-29. Retrieved from http://www.icrj.eu/13-741

Costa, F. \& D'Angelo, L. (2011). CLIL: A Suit for All Seasons. Latin American Journal of Content and Language Integrated Learning. http://doi. org/10.5294/laclil.2011.4.1.1

Coyle, D., Hood, P. \& Marsh, D. (2010). CLIL: Content and language integrated learning. Cambridge, UK: Cambridge University Press.

Doiz, A., Lasagabaster, D. \& Sierra, J. M. (2014). CLIL and motivation: The effect of individual and contextual variables. The Language Learning Journal, 42(2). http://doi.org/10.1080/09571736.2014.889508

Enkin, E. \& Mejías-Bikandi, E. (2016). Using online translators in the second language classroom: Ideas for advanced-level Spanish. Latin American Journal of Content \& Language Integrated Learning, 9(1), 138-158.

Favilli, F., Maffei, L. \& Peroni, R. (2012). Teaching/learning mathematics in a foreign language: Introducing CLILin Italy (pp. 6516-6521).

Gierlinger, E. M. \& Wagner, T. A. (2016). The more the merrier - revisiting CLIL-based vocabulary growth in secondary education. Latin American Journal of Content \& Language Integrated Learning, 9(1), 37-63. http://doi.org/10.5294/laclil.2016.8.1.3

Graddol, D. (1998). The future of the English language. The British Council, 1-66. http://doi.org/10.1017/So266078400000754

Graddol, D. (2006a). English next. 2006, (September 2008), 81-83. http:// doi.org/10.1093/elt/cclo50

Graddol, D. (2006b). English next: Why global English may mean the end of "English as a foreign language." London, UK: The British Council. Retrieved from http://www.britishcouncil.org/learning-researchenglish-next.pdf

Grandinetti, M., Langellotti, M. \& Ting, Y. L. T. (2013). How CLIL can provide a pragmatic means to renovate science education - even in a suboptimally bilingual context. International Journal of Bilingual 
Education \& Bilingualism, 16(March 2015), 354-374. http://doi.org /10.1080/13670050.2013.777390

Jäppinen, A. K. (2005). Thinking and content learning of mathematics and science as cognitional development in Content and Language Integrated Learning (CLIL): Teaching through a foreign language in Finland. Language and Education, 19(2), 147-168. http://doi. org/10.1080/09500780508668671

Lasagabaster, D. \& Sierra, J. M. (2009). Language attitudes in CLIL and traditional EFL classes. International CLIL Research Journal, 1,4-17.

Lasagabaster, D. (2011). English achievement and student motivation in CLIL and EFL settings. Innovation in Language Learning and Teaching, 5(1), 3-18. http://doi.org/10.1080/17501229.2010.519030

López Medina, B. (2016). Developing a CLIL textbook evaluation checklist. Latin American Journal of Content \& Language Integrated Learning, 9(1), 159-173. http://doi.org/10.5294/laclil.2016.8.1.7

Massler, U., Stotz, D. \& Queisser, C. (2014). Assessment instruments for primary CLIL: The conceptualisation and evaluation of test tasks. Language Learning Journal, 42(June 2014), 137-150. http://doi.org /10.1080/09571736.2014.891371

McDougald, J. S. (2009). The state of language and content instruction in Colombia. Latin American Journal of Content and Language Integrated Learning, 2(2), 44-48. http://doi.org/10.5294/ laclil.2009.2.2.15

McDougald, J. S. (2015). CLIL A fresh approach to bilingual learning. Ruta Maestra, 11,30-38. Retrieved from http://www.santillana.com.co/ rutamaestra/edicion-11/articles/5

McDougald, J. S. \& Anderson, C. E. (2015). CLIL and education coming together: The crossroads for multilingualism. Latin American Journal of Content and Language Integrated Learning, 8(2), LXXIIILXXXIII. http://doi.org/10.5294/laclil.2015.8.2.1

McGregor, M. J. J. (2016). Cognate effect and lexical processing in EnglishSpanish and Spanish-English bilinguals. Latin American Journal of Content \& Language Integrated Learning, 9(1), 174-209. http:// doi.org/10.5294/laclil.2016.8.1.8 
Mehisto, P. (2012). Criteria for producing CLIL learning material. Encuentro, 21, 15-33. Retrieved from http://files.eric.ed.gov/fulltext/ ED539729.pdf

Merikivi, R., \& Pietilä, P. (2014). Vocabulary in CLIL and in mainstream education. Journal of Language Teaching and Research, 5(3), 487497. http://doi.org/10.4304/jltr.5.3.487-497

Meyer, O. (2010). Towards quality CLIL: Successful planning and teaching strategies. Pulso: Revista de Educación, 33, 11-29. Retrieved from http://revistapulso.cardenalcisneros.es/documentos/ articulos/114.pdf

Novotná, J., \& Hofmannová, M. (2000). CLIL and mathematics education. Proceedings of the International Conference on "Mathematics for Living:The Mathematics Education Into the 21st Century Project," (Clil), 226-230.

Ouazizi, K. (2016). The effects of CLIL education on the subject matter (mathematics) and the target language (English). Latin American Journal of Content \& Language Integrated Learning, 9(1), 110-137. http://doi.org/10.5294/laclil.2016.8.1.5

Pistorio, M. I. (2009). Teacher training and competences for effective CLIL teaching in Argentina. Latin American Journal of Content \& Language Integrated Learning, 2(2), 37-43. http://doi.org/10.5294/ laclil.2009.2.2.14

Rodríguez, M. (2011). CLILL: Colombia leading into content language learning. Íkala, 16(28), 79-89.

Sulista, M. (2015). Incidental vocabulary acquisition from a bilingual textbook of financial mathematics. Efficiency and Responsibility in Education 2015, 556-562.

Toh, G. (2016). Extrapolating from an Inquiry into Curricular Issues Concerning the Adoption of English as Medium of Instruction in a Japanese University Situation. Latin American Journal of Content \& Language Integrated Learning, 9(1), 210-235. http://doi. org/10.5294/laclil.2016.8.1.9

Xanthou, M. (2011). The impact of CLIL on L2 vocabulary development and content knowledge. English Teaching, 10(4), 116-126. 
Yang, W. (2016). An investigation of learning efficacy, management difficulties and improvements in tertiary CLIL (Content and Language Integrated Learning) programmes in Taiwan: A survey of stakeholder perspectives. Latin American Journal of Content \& Language Integrated Learning, 9(1), 64-109. http://doi.org/10.5294/ laclil.2016.8.1.4

\title{
Editor's Note
}

\section{Retraction of "Project work in CLIL: A bibliographical review"}

\author{
Retractación de "El trabajo de proyectos en CLIL: \\ una revisión bibliográfica”
}

The article "Project work in CLIL: A bibliographical review" has been retracted at the request of the authorities of the Universidad Católica San Antonio de Murcia (Murcia, Spain) as the manuscript was found to contain a substantial amount of content derived without credit or citation from the unpublished work of researchers at that institution.

Por petición de las autoridades de la Universidad Católica San Antonio de Murcia (Murcia, España) el artículo "El trabajo de proyectos en CLIL: una revisión bibliográfica” ha sido retirado, ya que el manuscrito contiene información sin la correspondiente citación o crédito de trabajos inéditos de investigadores de esa institución.

Reference

Casan-Pitarch, R. (2015). Project work in CLIL: A bibliographical review. Latin American Journal of Content and Language Integrated Learning, 8(2), 212-236. doi:10.5294/laclil.2015.8.2.7 